\title{
ALLT SOM ÄR FAST FÖRFLYKTIGAS
}

Frasen som Marshall Berman lyfte fram ur Marx-Engels kommunistiska manifest används ofta numera när tidens föränderlighet, snabba förbrukning av materiella och immateriella bekvämligheter begrundas. Den ligger nära till hands när Chris Dercon - i numrets uppsats om det moderna konstmuseet - i förbigående nämner svårigheten att 1996 rekonstruera Four Rotating Walls, en installation som 1970 förvärvats till Boijmans Van Beuningen-museet i Rotterdam och som byggde på filmprojektioner. Många konstmuseer, konstaterar han, har upptäckt att de kunnat befria utställningsrummen från illusionen att representera en stillastående värld med hjälp av bild- och filmprojektioner, bildspel, batterier av bildskärmar med videoprojektioner som automatiskt upprepas, interaktiva datorer som kopplas upp till Internet och lyfter in yttervärlden i rummet. Men till vilket pris?

Informationsteknologins nyheter upphör aldrig att förföra - man förleds att tro att både kunskap och upplevelse på ett oöverträffat sätt kommuniceras av en alltmer sofistikerad illusionsapparatur. Museer, angelägna att vidga sin publik, satsar entusiastiskt på projektorer, bildspel och video, videokanoner som också kan användas för digital teknik. Allt i den mediala konkurrensens namn. Men teknikgenerationerna avlöser varandra obönhörligt, apparaterna blir museala(!) och svåra att bibehålla brukbara för de dokumentationer och presentationsprogram som en gång producerats just för dem. Ska den oundvikliga kostnaden satsas på restaurering av hårdvaran eller konvertering av mjukvaran till en nyss lanserad medial teknik? Eller ska man - Dercon antyder det som ett alternativ - på allvar ta ställning för museerna som en plats för kontemplation, för betraktande av det stillastående konkret synliga och reellt påtagliga, där elektroniska medier endast efter noggrant övervägande ges en subsidiär fördjupande eller kompletterande uppgift? På ett diskret sätt underordnade utställningens visualitet.

Den senaste diskussionen gäller det virtuella museet och den virtuella utställningen. Åter en svår prioriteringsfråga i museernas resursallokering till förmån för en 
teknik med (som alla vet) hypersnabb generationsväxling. $\AA$ ena sidan erbjuds möjligheten av att öka museisamlingars tillgänglighet - om nu ett digitalt nätverk finns, eller byggs ut, för den 'legitima' publiken. $\AA$ andra sidan är upphovsrättsfrågan komplicerad om text- och bildmaterial ska läggas ut på ett gränslöst Internet. Och den raffinerade möjligheten att komplettera med rörliga bildsekvenser och ljud ställer krav på användarsidans tekniska kapacitet och beredskap för uppdatering. Konstnärer som vill nå en bred publik, vända sig till samhället, ser den virtuella utställningen som en lockande möjlighet. Men vem betalar för offentliggörandet av - de kanske också digitalt producerade - verken, som i virtuell mening löper risk att verkligen förflyktigas om de inte förts över till ett lagringsmedium. Och är ens begreppet virtuell utställning acceptabelt?

1900-talets sista nummer av Nordisk Museologi ger plats åt fyra favoritteman. Museipedagogik tas upp i Torun Ekelands översikt av den didaktik som tillämpats i förmedlingen av den arkeologiska forskarens syn på förhistorien och i Ritva Palviainens erfarenheter av ett museums roll i det livslånga lärandet. Museiarkitektur och utställningar tas upp i Ase Enerstvedts kritiska husesyn i det nya skotska nationalmuseet och i Chris Dercons synpunktsrika föreläsning (i danska Museumshøjskolen) om det moderna konstmuseet. Ekomuseer behandlas i An Laishuns och John Aage Gjestrums rapport från det första kinesiska ekomuseet samt av Mathilde Bellaigue som med sin unika erfarenhet av ekomuseets historiska utveckling ger ett framtidsperspektiv - inte bara på ekomuseerna. Svensk museihistoria handlar Claes Hallgrens och Christer Nordlunds bidrag om, men anknyter tematiskt samtidigt till både museipedagogik och utställningar.

Vidare återges Göran Bolins mycket uppmärksammade föreläsning från konstmuseiseminariet i Norrköping förra året. Den ansluter, visar det sig, väl till den aktuella svenska debatt om de etiska följderna av att att töja kulturuttryckens estetiska gränser som följt på Lars Noréns senaste teaterprojekt och höstens filmfestival i Stockholm.

Per-Uno Agren

Apropå allt skrivande Ingen berättelse är oskyldig och ingen berättar utan makt. Steve Sem-Sandberg i Sv. Dagbladet 23/11. 